\title{
Review Article \\ Nanocatalysts for Hydrogen Generation from Ammonia Borane and Hydrazine Borane
}

\author{
Zhang-Hui Lu, Qilu Yao, Zhujun Zhang, Yuwen Yang, and Xiangshu Chen \\ College of Chemistry and Chemical Engineering, Jiangxi Normal University, Nanchang 330022, China \\ Correspondence should be addressed to Zhang-Hui Lu; luzh@jxnu.edu.cn and Xiangshu Chen; cxs66cn@jxnu.edu.cn
}

Received 15 February 2014; Accepted 26 February 2014; Published 14 April 2014

Academic Editor: Ming-Guo Ma

Copyright (C) 2014 Zhang-Hui Lu et al. This is an open access article distributed under the Creative Commons Attribution License, which permits unrestricted use, distribution, and reproduction in any medium, provided the original work is properly cited.

\begin{abstract}
Ammonia borane (denoted as $\mathrm{AB}, \mathrm{NH}_{3} \mathrm{BH}_{3}$ ) and hydrazine borane (denoted as $\mathrm{HB}, \mathrm{N}_{2} \mathrm{H}_{4} \mathrm{BH}_{3}$ ), having hydrogen content as high as $19.6 \mathrm{wt} \%$ and $15.4 \mathrm{wt} \%$, respectively, have been considered as promising hydrogen storage materials. Particularly, the $\mathrm{AB}$ and $\mathrm{HB}$ hydrolytic dehydrogenation system can ideally release $7.8 \mathrm{wt} \%$ and $12.2 \mathrm{wt} \%$ hydrogen of the starting materials, respectively, showing their high potential for chemical hydrogen storage. A variety of nanocatalysts have been prepared for catalytic dehydrogenation from aqueous or methanolic solution of $\mathrm{AB}$ and $\mathrm{HB}$. In this review, we survey the research progresses in nanocatalysts for hydrogen generation from the hydrolysis or methanolysis of $\mathrm{NH}_{3} \mathrm{BH}_{3}$ and $\mathrm{N}_{2} \mathrm{H}_{4} \mathrm{BH}_{3}$.
\end{abstract}

\section{Introduction}

Hydrogen, as a globally accepted clean and source-independent energy carrier, has a high energy content per mass $(120 \mathrm{MJ} / \mathrm{kg})$ compared to petroleum $(44 \mathrm{MJ} / \mathrm{kg})$. It can serve as energy source for different end uses, such as hydrogen fuel cell vehicles and portable electronics [1], which will enable a secure and clean energy future. The use of hydrogen fuel cells in portable electronic devices or vehicles requires lightweight hydrogen storage or on-board hydrogen production. For vehicular applications, the US Department of Energy (DOE) has set storage targets; the gravimetric and volumetric system targets for near-ambient temperature and moderate pressure are $9.0 \mathrm{wt} \%$ and $81 \mathrm{~g} / \mathrm{L}$ for 2015 , respectively. In order to meet the targets set by the US DOE, various storage solutions have been developed and a large number of studies have been performed on the hydrogen storage materials [2-9], such as metal hydrides [2], organic hydrides [10], and metal organic frameworks [11]. However, big challenges still remain.

Chemical storage materials with low molecular weight and high gravimetric hydrogen density are highly promising as hydrogen sources [12-14]. Particularly, ammonia borane $\left(\mathrm{AB}, \mathrm{NH}_{3} \mathrm{BH}_{3}\right)$ and hydrazine borane $\left(\mathrm{HB}, \mathrm{N}_{2} \mathrm{H}_{4} \mathrm{BH}_{3}\right)$ have attracted much attention. The simplest $\mathrm{B}-\mathrm{N}$ compound of ammonia borane, which has a hydrogen capacity as high as
$19.6 \mathrm{wt} \%$ and a low molecular weight $(30.9 \mathrm{~g} / \mathrm{mol})$, exceeding that of gasoline and $\mathrm{Li} / \mathrm{NaBH}_{4}$, has made itself an attractive candidate for chemical hydrogen storage applications [14]. The closely related compound hydrazine borane contains $15.4 \mathrm{wt} \%$ of hydrogen, which is greater than the 2015 target of US DOE, and needs to be considered as another B-N compound that can be used for the storage of hydrogen [15].

Ammonia borane and hydrazine borane can release their hydrogen through thermal dehydrogenation in solid state and solvolysis (hydrolysis and methanolysis) in solution [12]. Generally speaking, thermal dehydrogenation process requires high temperature and power consumption. In contrast, ammonia borane and hydrazine borane are able to release hydrogen via a room temperature solvolysis reaction in the presence of a suitable catalyst [5, 12, 15]. Various nanocatalysts have been tested for hydrogen generation from the solvolysis of $\mathrm{AB}$ and $\mathrm{HB}$. This review is to serve as an up-to-date account of the recent progress in nanocatalysts for hydrogen generation from $\mathrm{AB}$ and $\mathrm{HB}$.

\section{Ammonia Borane}

Ammonia borane is a colorless molecular crystal under ambient conditions with a density of $0.74 \mathrm{~g} \mathrm{~cm}^{-3}$ and soluble 


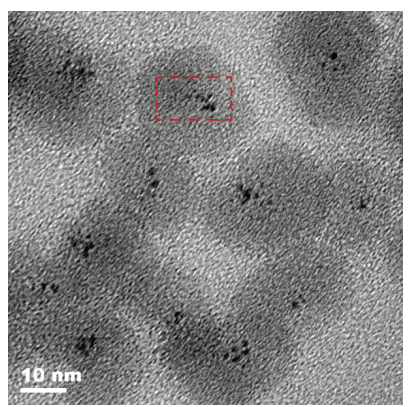

(A)

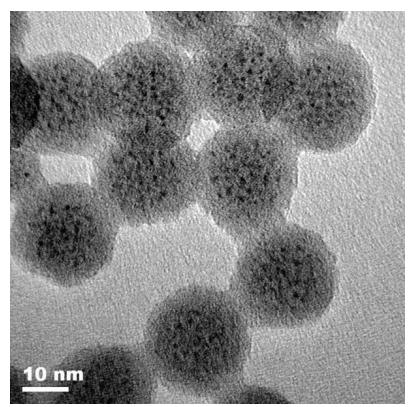

(C)

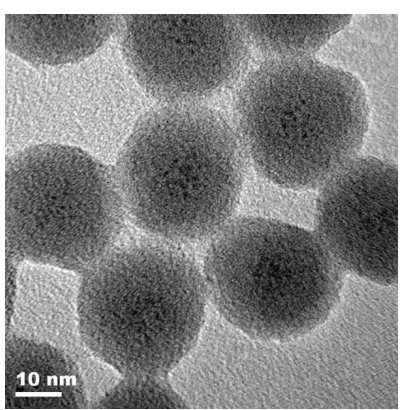

(B)

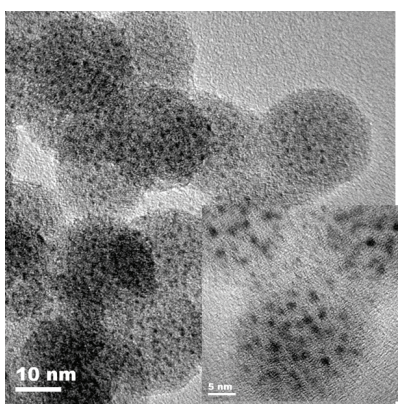

(D)

(a)

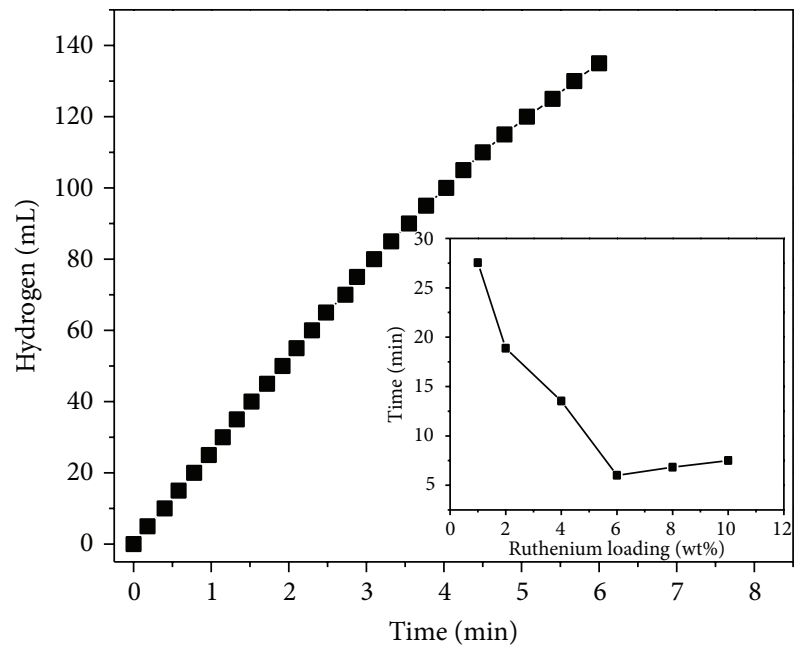

(b)

Figure 1: (a) Representative TEM images of the core-shell NPs Ru@SiO ${ }_{2}$ with different Ru loadings: (A) 1 wt $\%$, (B) 2 wt $\%$, (C) 6 wt $\%$, and (D) $10 \mathrm{wt} \%$. (b) Hydrogen generation from hydrolysis of $\mathrm{NH}_{3} \mathrm{BH}_{3}(200 \mathrm{mM}, 10 \mathrm{~mL})$ by $\mathrm{Ru} @ \mathrm{SiO}_{2} \mathrm{NPs}(\mathrm{Ru}$ loading $=6 \mathrm{wt} \% \mathrm{and}(\mathrm{Ru})=0.5 \mathrm{mM})$ at $298 \mathrm{~K}$. The inset shows the reaction time versus the loading of ruthenium. Reprinted with the permission from [38]. Copyright: 2014 Elsevier.

in water and other relatively polar solvents. The hydrogen stored in $\mathrm{AB}$ can be released either by thermolysis in solid state and nonaqueous medium or metal catalyzed reactions in protic solvents (water and methanol) [14]. About $1 \mathrm{~mol}$ $\mathrm{H}_{2}$ (i.e., $6.5 \mathrm{wt} \% \mathrm{H}$ ) per mol $\mathrm{AB}$ is released by thermal decomposition of $\mathrm{AB}$ under moderate conditions $\left(<100^{\circ} \mathrm{C}\right)$ [14]. However, to maximize the use of hydrogen in $A B$ higher temperature is needed, which also results in the release of the side product borazine. To reduce the threshold temperature and volatile byproducts, a number of approaches have been achieved, including dehydrogenating $\mathrm{AB}$ on nanoscaffolding [16], catalytic modifications [17], dispersion in an ionic liquid [18], and the synthesis of derivatives (e.g., metal amidoboranes) [9].

Thermal decomposition of $\mathrm{AB}$ usually required high temperature and the reaction was relatively difficult to control. In contrast, the catalytic hydrolysis or methanolysis provides a more convenient strategy for hydrogen generation from $\mathrm{AB}$ [19-25]. In the presence of a suitable catalyst, hydrolysis of $\mathrm{AB}$ can release as much as $3 \mathrm{~mol}$ of hydrogen per mol of $\mathrm{AB}$ at room temperature via the following reaction:

$$
\mathrm{NH}_{3} \mathrm{BH}_{3}+2 \mathrm{H}_{2} \mathrm{O} \longrightarrow \mathrm{NH}_{4} \mathrm{BO}_{2}+3 \mathrm{H}_{2}
$$

In 2006, noble metal (Pt, $\mathrm{Ru}$, and $\mathrm{Pd}$ ) nanocatalysts were firstly found by Xu's group to have considerable activities toward hydrolytic dehydrogenation of $\mathrm{AB}$ [26]. The $\mathrm{Al}_{2} \mathrm{O}_{3}$, $\mathrm{C}$, and $\mathrm{SiO}_{2}$ supported noble metals ( $\mathrm{Ru}, \mathrm{Rh}, \mathrm{Pd}, \mathrm{Pt}$, and $\mathrm{Au}$ ) nanoparticles were also investigated for hydrolysis of $\mathrm{AB}$ [27].
Among them, Pt-based nanocatalysts were found to be most active. Recently, ultrafine Pt NPs immobilized inside metal organic framework (MIL-101) were synthesized as highly efficient catalysts for hydrolytic dehydrogenation from AB [28]. Metin and coworkers found that the poly(4-styrenesulfonic acid-co-maleic acid) (PSSA-co-MA) stabilized $\mathrm{Ru}$ and $\mathrm{Pd}$ NPs having average particle size of $1.9 \pm 0.5$ and $3.5 \pm 1.6 \mathrm{~nm}$, respectively [29], were highly active catalysts for hydrolysis of $\mathrm{AB}$. In addition, $\mathrm{Ru}, \mathrm{Rh}$, and Pd NPs stabilized by xonotlite [30], zeolite [31], hydroxyapatite [32], aluminum oxide [33], carbon black [34], carbon nanotubes [35], and graphene $[36,37]$ were also reported to have good catalytic activity in the hydrolytic dehydrogenation of AB. Particularly, the activation energy for the hydrolysis of $A B$ in the presence of $\mathrm{Ru} /$ graphene was reported to be $11.7 \mathrm{~kJ} / \mathrm{mol}$ [37], which is the lowest value ever reported for the same reaction. More recently, $\mathrm{Ru}$ NPs embedded in $\mathrm{SiO}_{2}$ nanospheres $\left(\mathrm{Ru} @ \mathrm{SiO}_{2}\right.$ core-shell NPs) have been synthesized by us and used as catalysts for hydrolysis of $\mathrm{AB}$ [38], as shown in Figure 1. The characterized results show that ultrafine $\mathrm{Ru}$ nanoparticles (NPs) of around $2 \mathrm{~nm}$ are effectively embedded in the center of well-proportioned spherical and porous silica nanospheres ( $\sim 25 \mathrm{~nm}$ in diameter). Interestingly, the number of Ru NPs increases inside the spherical particles of $\mathrm{SiO}_{2}$ as the increase of Ru loading. The as-synthesized Ru@SiO ${ }_{2}$ exhibited high catalytic activity and good durability for hydrogen generation from $\mathrm{AB}$.

The noble metal-based catalysts provide significant catalytic activities in hydrogen generation from hydrolysis of 
AB. For practical use, the development of low-cost and highly efficient catalysts is desired. Therefore, the development of efficient and economical nonnoble catalysts to further improve the kinetic properties is of great importance for the practical application of hydrogen generation/storage systems. The nonnoble metals (i.e., Fe, $\mathrm{Co}, \mathrm{Ni}$, and $\mathrm{Cu}$ ) containing catalysts have been extensively investigated in the past several years [39-51], and among them, Co-based catalysts with similar structure or stabilizer were found to have the highest catalytic activity. The $\gamma-\mathrm{Al}_{2} \mathrm{O}_{3}, \mathrm{SiO}_{2}$, and $\mathrm{C}$ supported nonoble metals (Co, Ni, and $\mathrm{Cu}$ ) NPs were reported to be catalytically active, whereas supported Fe NPs were inactive for catalytic hydrolysis of AB [39]. Unexpectedly, amorphous Fe NPs synthesized by in situ reduction with $\mathrm{AB}$ and $\mathrm{NaBH}_{4}$ exhibited the noble metal-like catalytic activity in the hydrolysis of $\mathrm{AB}(\mathrm{Fe} / \mathrm{AB}=0.12)$ [40]. And then, the amorphous Co and Ni NPs were also found to have enhanced catalytic performance in comparison to their crystalline counterparts [41-43]. The high activity of the amorphous metal NPs could be attributed to the amorphous structure, which has a much greater structural distortion and therefore a much higher concentration of active sites for the reaction than its crystalline counterpart.

Unexpectedly, monodisperse $3.2 \mathrm{~nm}$ Ni NPs with a polycrystalline structure, supported on Ketjen carbon black [44], were shown to be a highly active catalyst for the hydrolysis of $\mathrm{AB}$, with the total turnover frequency (TOF) reaching $8.8 \mathrm{~mol}^{-1} \mathrm{H}_{2} \mathrm{~mol}^{-1} \mathrm{Ni} \mathrm{min}{ }^{-1}$. But this $\mathrm{Ni} / \mathrm{C}$ catalyst was not stable during the hydrolysis reaction due to the agglomeration of Ni NPs on the carbon support. $3.2 \mathrm{~nm} \mathrm{Ni} \mathrm{NPs}$ supported on $\mathrm{SiO}_{2}$ were found by the same group to have the excellent activity and durability [45]. Recently, the Ni NPs $(6.3 \pm 1.7 \mathrm{~nm})$ deposited into the nanoporous carbon (MSC30) showed an excellent catalytic activity with a TOF value as high as $30.7\left(\mathrm{~mol}^{-1} \mathrm{H}_{2} \mathrm{~mol}^{-1} \mathrm{Ni} \mathrm{min}^{-1}\right)$ [46], which is the highest one among all of the Ni nanocatalysts ever reported for this reaction at room temperature.

Compared to the Fe-, Co-, and Ni-based catalysts, the $\mathrm{Cu}$-based catalysts were reported to have a lower catalytic activity [52-57]. Iron, cobalt, and nickel oxides formed from the corresponding metals under atmosphere condition were difficult to be reduced by weak reductants such as $\mathrm{AB}$. Thus, before use to attain an effective catalyst, reductive pretreatment is necessary. However, copper oxides are easily reduced by a milder reductant (such as $\mathrm{AB}$ ) and are exceptional catalysts working without reductive pretreatment in catalytic hydrolysis of $\mathrm{AB}$. Nanostructured $\mathrm{Cu}, \mathrm{Cu}_{2} \mathrm{O}$, and $\mathrm{Cu} @ \mathrm{Cu}_{2} \mathrm{O}$ NPs synthesized by the solvated metal atom dispersion (SMAD) method were tested for the hydrolysis of $\mathrm{AB}$ [53]. $\mathrm{Cu} @ \mathrm{Cu}_{2} \mathrm{O}$ showed better catalytic activity than $\mathrm{Cu}$ and $\mathrm{Cu}_{2} \mathrm{O}$. A series of $\mathrm{Co}_{3} \mathrm{O}_{4}$ NPs in which $\mathrm{Cu}$ was loaded on the surface were examined as catalysts in the hydrolysis of AB [54]. Their catalytic activity was dependent on the shape and size of nanosized $\mathrm{Co}_{3} \mathrm{O}_{4}$. Recently, capping of $\mathrm{Cu}_{2} \mathrm{O}$ with organic reagents or inorganic materials was performed and tested in $\mathrm{AB}$ hydrolysis [55]. It was found that capping of $\mathrm{Cu}_{2} \mathrm{O}$ with 50 -facet $\mathrm{Co}_{3} \mathrm{O}_{4}$ NPs was the most active. $\mathrm{Cu}$ NPs supported on silica-coated cobalt(II) ferrite $\mathrm{SiO}_{2} / \mathrm{CoFe}_{2} \mathrm{O}_{4}$
(CuNPs@SCF) were reported to have an initial TOF value of $2400 \mathrm{~mol} \mathrm{H}_{2} \mathrm{~mol}^{-1} \mathrm{Cu} \mathrm{h}^{-1}$ in air at room temperature [56]. They claimed that the TOF value was the highest one among the first row metal catalysts used in the hydrolysis of $\mathrm{AB}$. It was noted that the $\mathrm{CoFe}_{2} \mathrm{O}_{4}$ of the support was not considered in the TOF test. Iron and cobalt oxides were difficult to be reduced by $\mathrm{AB}$; however, they might be reduced by the $\mathrm{Cu}-\mathrm{H}$ active species or $\mathrm{H}_{2}$ generated in the hydrolysis reaction. In addition, zeolite and hydrogel networks-confined $\mathrm{Cu}$ NPs were synthesized and used as catalyst systems [48]. Graphene-supported $\mathrm{Cu}$ NPs were synthesized by us via a facile in situ procedure using $\mathrm{AB}$ as a reductant, which exert satisfied catalytic activity $\left(3.61 \mathrm{~mol} \mathrm{H}_{2}\right.$ mol catalyst ${ }^{-1} \mathrm{~min}^{-1}$ ) [57], appearing to be the best $\mathrm{Cu}$ nanocatalysts up to now.

Bimetallic catalysts usually show improved catalytic performance in comparison to their monometallic counterparts; due to that the metal-metal interactions in the bimetallic systems presumably account for the tuning of the bonding pattern of reactants and stabilization of reaction intermediates on the catalyst surface. A number of bimetallic catalysts [58-73], such as Au-Co [58, 59], Au-Ni [60, 61], Ru-Co [62], Ru-Ni [63, 64], Ru-Cu [62], Pt-Ni [65, 66], Pd-Co [67], Cu-Co [68, 69], Cu-Fe [70], Fe-Ni [71], Fe-Co [72], and $\mathrm{Co}-\mathrm{Ni}$ [73], have been employed in the hydrolysis of AB. For example, small Au-Ni and Au-Co NPs (2-4 nm) embedded in $\mathrm{SiO}_{2}$ nanospheres (about $15 \mathrm{~nm}$ ) exhibited superior performance in the hydrolysis of $\mathrm{AB}[58,61]$, in contrast to monometallic counterparts $\mathrm{Au} @ \mathrm{SiO}_{2}, \mathrm{Ni@SiO}$, and $\mathrm{Co@SiO}$. After heat treatment in vacuum, multiple AuCo NPs embedded in $\mathrm{SiO}_{2}$ nanospheres merged into single $\mathrm{Au}-\mathrm{Co}$ NPs within $\mathrm{SiO}_{2}$, resulting in a size increase of the bimetallic core NPs [58], as shown in Figure 2. Unexpectedly, single Au-Co NPs within $\mathrm{SiO}_{2}$ showed a better catalytic activity than multiple small bimetallic core NPs within $\mathrm{SiO}_{2}$, which is due to the decrease in the content of basic ammine by the decomposition of metal ammine complexes (precursor) during the heat treatment.

Bimetallic NPs with core-shell architecture have attracted growing attention in recent years due to their unique and novel optical, electrical, and catalytic properties compared with their monometallic counterparts and alloys. Yan and coworkers prepared Au@Co core-shell NPs through the onestep seeding growth route with $\mathrm{AB}$ as the reductant [59]. By exposing a mixture of $\mathrm{Au}^{3+}$ and $\mathrm{Co}^{2+}$ precursors to the aqueous solution of $\mathrm{AB}$ at the same time, the core Au NPs can be formed first and then serve as the in situ seeds for successive catalytic reduction leading to the growth of outer shell Co NPs, which is to take advantage of the difference in reduction potentials of the two metal ions. A relative stronger reductant $\mathrm{NaBH}_{4}$, instead of $\mathrm{AB}$, causes the formation of Au-Co alloys. Therefore, a suitable reductant is essential in this one-step synthesis method. Compared to alloy and monometallic counterparts, the Au@Co NPs exhibited excellent catalytic activity and long-term stability in the hydrolysis of $\mathrm{AB}$. A similar approach was used to synthesize bimetallic Cu@M [74], Pd@M [75], Ag@M [76], and Ru@M (M = Fe, Co, Ni) [77] and trimetallic Au@Co@Fe [78], Cu@FeNi [79], Cu@CoNi [80], Cu@FeCo [81], Cu@CoCr [82], Ag@CoFe 


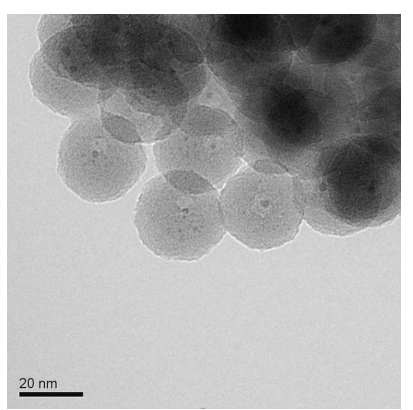

(A)

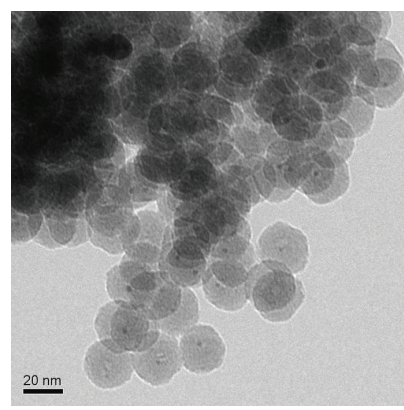

(C)

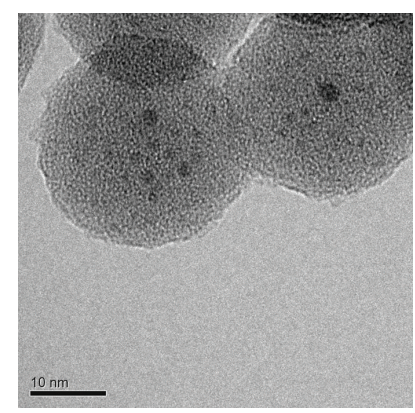

(B)

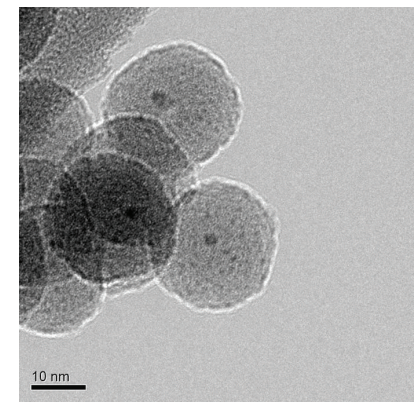

(D)

(a)

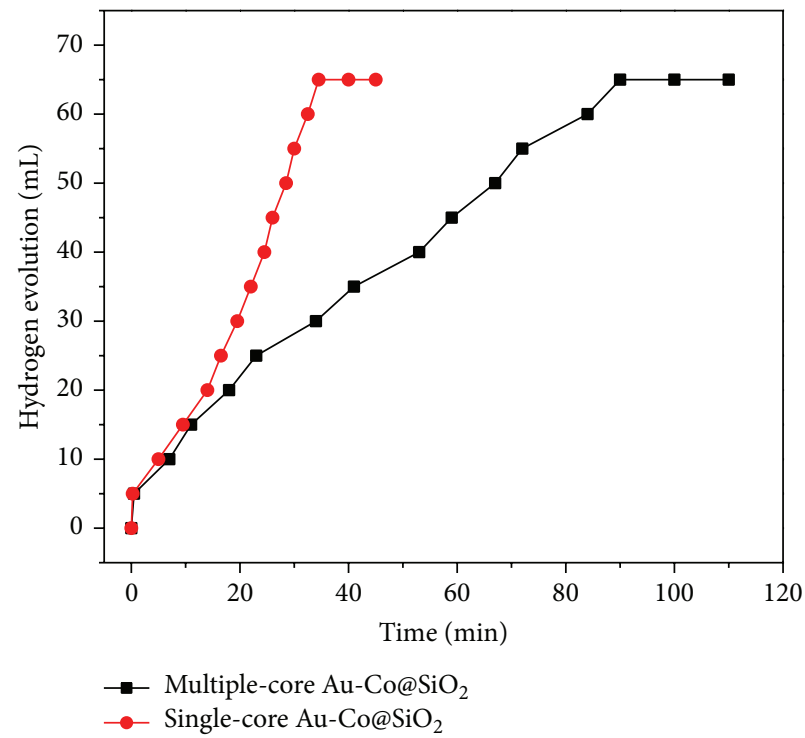

(b)

FIgURE 2: (a) Representative TEM images of the core-shell NPs Au-Cu@SiO ${ }_{2}$ with multiple- (A-B) and single-core (C-D) NPs. (b) Hydrogen generation from hydrolysis of $\mathrm{NH}_{3} \mathrm{BH}_{3}(160 \mathrm{mM}, 5 \mathrm{~mL})$ by different catalysts at $298 \mathrm{~K}$. Reprinted with the permission from [58]. Copyright: 2012 Royal Society of Chemistry.

[83], Ag@NiFe [83], Ag@CoNi [84], and Ag@Co@Ni [85] core shell NPs. It was found that all the obtained bimetallic or trimetallic core-shell NPs showed higher activities than the corresponding monometallic counterparts in the hydrolysis of $\mathrm{AB}$. However, the $\mathrm{Cu}-\mathrm{Fe}$ bimetallic nanoalloys synthesized by in situ reduction of $\mathrm{Cu}^{2+}$ and $\mathrm{Fe}^{2+}$ with $\mathrm{AB}$ and $\mathrm{NaBH}_{4}$ as the reductant exhibited excellent catalytic activity, especially for $\mathrm{Cu}_{0.33} \mathrm{Fe}_{0.67}$ alloy NPs outperforming the activity of monometallic counterparts and even of $\mathrm{Cu}_{0.33} @ \mathrm{Fe}_{0.67}$ coreshell NPs [70], as shown in Figure 3.

Besides the hydrolysis of $\mathrm{AB}$, the methanolysis reaction has also taken place in the presence of suitable catalysts and has been developed to generate hydrogen. This catalytic methanolysis reaction can be expressed as follows:

$$
\mathrm{NH}_{3} \mathrm{BH}_{3}+4 \mathrm{MeOH} \longrightarrow \mathrm{NH}_{4} \mathrm{~B}(\mathrm{OMe})_{4}+3 \mathrm{H}_{2}
$$

The hydrogen capacity from this methanolysis reaction is estimated to be about $3.9 \mathrm{wt} \%$, lower than that from the hydrolysis reaction $(8.9 \mathrm{wt} \%)$. However, the hydrolytic system with high-concentration $\mathrm{AB}$ solution can lead to the release of small quantities of $\mathrm{NH}_{3}$ along with $\mathrm{H}_{2}$, whereas the methanolysis of $\mathrm{AB}$ can overcome this problem. What is more, the methanolysis product of $\mathrm{NH}_{4} \mathrm{~B}(\mathrm{OMe})_{4}$ can be converted back to $\mathrm{AB}$ by treatment of lithium aluminium hydride with ammonium chloride. In $2007, \mathrm{RuCl}_{3}$, $\mathrm{RhCl}_{3}, \mathrm{PdCl}_{2}, \mathrm{CoCl}_{2}, \mathrm{NiCl}_{2}, \mathrm{Pd} / \mathrm{C}$, and Raney-Ni were firstly reported for the methanolysis of $\mathrm{AB}$ [86]. Since then, various catalysts have been examined in hydrogen generation from the methanolysis of $\mathrm{AB}$, such as PVP-stabilized Pd and $\mathrm{Ru}$ NPs $[87,88], \mathrm{Ru}$ NPs immobilized in montmorillonite [89], $\mathrm{Co}-\mathrm{Co}_{2} \mathrm{~B}, \mathrm{Ni}-\mathrm{Ni}_{3} \mathrm{~B}, \mathrm{Co}-\mathrm{Ni}-\mathrm{B}$ [90], zeolite stabilized $\mathrm{Rh}$ NPs [91], and $\mathrm{Cu} @ \mathrm{Cu}_{2} \mathrm{O}$ [53]. Recently, monodisperse $7 \mathrm{~nm}$ CoPd NPs with controlled compositions were synthesized and used for catalytic methanolysis of $\mathrm{AB}$ [92]. The CoPd NPs showed the composition-dependent methanolysis at room temperature, with $\mathrm{Co}_{48} \mathrm{Pd}_{52} / \mathrm{C}$ being the most active. More recently, various mesoporous $\mathrm{Cu}$ nanostructures with diverse morphologies have been synthesized by us via a facile and scaleable wet-chemical method and applied as catalyst for hydrogen generation from the methanolysis of $A B$ [93]. Among them, the flower-like mesoporous $\mathrm{Cu}$ showed the highest catalytic activity.

Catalytic hydrolysis or methanolysis reaction of $\mathrm{AB}$ proceeds with rapid kinetics in the presence of suitable metal nanocatalysts at ambient temperatures. A portable hydrogen generation system is expected to be established on the basis of the metal-catalyzed dehydrogenation of $\mathrm{AB}$. A significant drawback of the hydrolysis system is that $\mathrm{B}-\mathrm{H}$ bonds are converted to much stronger $\mathrm{B}-\mathrm{O}$ bonds. These byproducts with $\mathrm{B}-\mathrm{O}$ bonds generated during the hydrolysis reaction will be energetically costly to regenerate. Further experimental and theoretical researches toward the practical application, including the highly efficient catalyst with the low cost and long-time stability, and the regeneration of $A B$ are highly desired. Notably, the convenience and reliability of performing $\mathrm{AB}$ hydrolysis reaction make it suitable for application. Like $\mathrm{CO}$ oxidation, the hydrolysis of $\mathrm{AB}$ has 


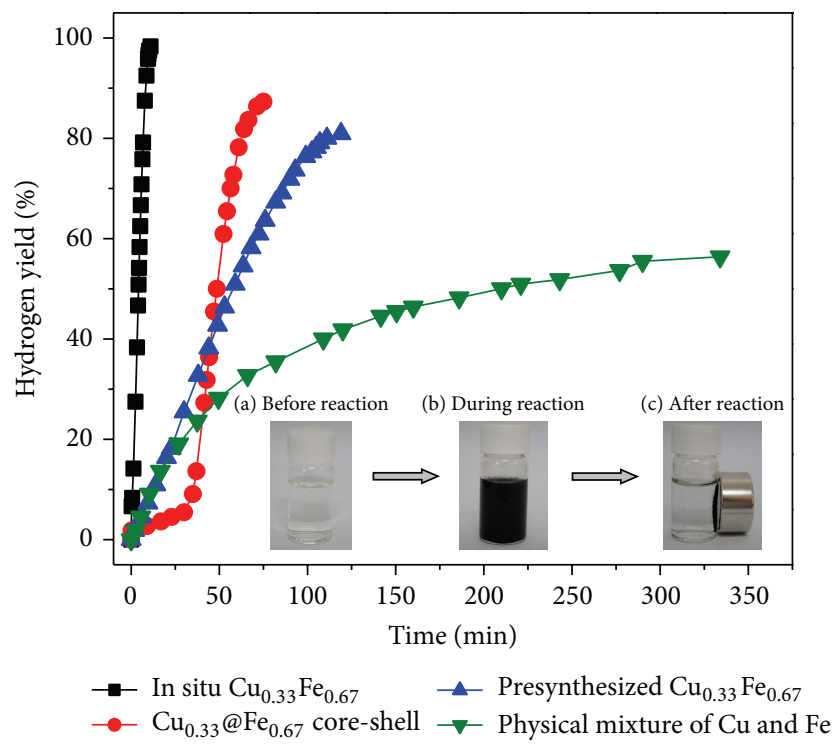

FIGURE 3: Hydrogen generation from the hydrolysis of $\mathrm{AB}$ in the presence of different metal nanocatalysts (metal $/ A B=0.04)$. The insert shows photographs of the catalytic hydrolysis of $\mathrm{AB}$ via in situ synthesized $\mathrm{Cu}_{0.33} \mathrm{Fe}_{0.67}$ nanoalloy. Reprinted with the permission from [70]. Copyright: 2013 Elsevier.

already been widely used as a test (model) reaction for examining the catalytic activity of new nanomaterials.

\section{Hydrazine Borane}

Hydrazine borane $\left(\mathrm{N}_{2} \mathrm{H}_{4} \mathrm{BH}_{3}, \mathrm{HB}\right)$ is one of the hydrogendense derivatives of ammonia borane and has a gravimetric hydrogen capacity of $15.4 \mathrm{wt} \%$, with $4 \mathrm{H}^{\delta+}$ and $3 \mathrm{H}^{\delta-}$. The first report concerning $\mathrm{HB}$ dates back to 1961 when Goubeau and Ricker published the synthesis $\mathrm{HB}$ by reaction of $\left(\mathrm{N}_{2} \mathrm{H}_{5}\right)_{2} \mathrm{SO}_{4}$ with $\mathrm{NaBH}_{4}$ in dioxane at room temperature [94]. Since then several studies were conducted [95-97], focusing on synthesis, decomposition, and hydrogen generating systems. Experimental spectroscopy and DFT calculation were performed to understand the structure of $\mathrm{HB}$ [98-100]. The release of hydrogen from $\mathrm{HB}$ can be obtained through either thermolysis or solvolysis. The thermal decomposition of solid HB was firstly studied by Goubeau and Ricker [94]. Hydrogen is released from $\mathrm{HB}$ in a controlled manner even at temperatures as high as $200^{\circ} \mathrm{C}$. In the presence of $\mathrm{LiH}, 11 \mathrm{wt} \%$ $\mathrm{H}_{2}$ can be released from $\mathrm{HB}$ at $150^{\circ} \mathrm{C}$ in less than an hour [15].

The hydrolysis of $\mathrm{HB}$ was firstly reported by Karahan and coworkers [4]. In the presence of $\mathrm{RhCl}_{3}$ precatalyst, the aqueous solution of $\mathrm{HB}$ undergoes fast hydrolysis to release nearly 3.0 equivalent of $\mathrm{H}_{2}$ with $\mathrm{TOF}=1200 \mathrm{~h}^{-1}$ by hydrolysis of the $\mathrm{BH}_{3}$ group. They also reported the preparation and characterization of the Rh NPs supported on hydroxylapatite $\left(\mathrm{Ca}_{10}(\mathrm{OH})_{2}\left(\mathrm{PO}_{4}\right)_{6}, \mathrm{HAP}\right)$ and their catalytic hydrolysis of $\mathrm{HB}$ with a TOF value of $6700 \mathrm{~h}^{-1}$ at room temperature [101]. The poly(4-styrenesulfonic acid-co-maleic acid) (PSSMA) stabilized Ni NPs formed during the hydrolysis of $\mathrm{HB}$ were found to be highly active catalyst releasing $2.6-3.0 \mathrm{~mol} \mathrm{H}_{2}$ per mol HB with an initial TOF value of $3.05 \mathrm{~min}^{-1}$ [102]. However, only about $3 / 7$ of its hydrogen was released by the hydrolysis of the $\mathrm{BH}_{3}$ group of $\mathrm{HB}$ and the $\mathrm{N}_{2} \mathrm{H}_{4}$ group was not decomposed:

$$
\mathrm{N}_{2} \mathrm{H}_{4} \mathrm{BH}_{3}+2 \mathrm{H}_{2} \mathrm{O} \longrightarrow \mathrm{N}_{2} \mathrm{H}_{5} \mathrm{BO}_{2}+3 \mathrm{H}_{2}
$$

Like the $\mathrm{BH}_{3}$ group of $\mathrm{AB}$, the $\mathrm{BH}_{3}$ group in $\mathrm{HB}$ is easy to hydrolyze in the presence of a suitable catalyst. However, unlike the $\mathrm{NH}_{3}$ group of $\mathrm{AB}$, the $\mathrm{N}_{2} \mathrm{H}_{4}$ group of $\mathrm{HB}$ can also be dehydrogenated in the presence of a selective catalyst (4), although this reaction is in competition with $\mathrm{NH}_{3}$ release (5). Therefore, $\mathrm{HB}$ is of great interest in hydrolysis because the $\mathrm{H}$ atoms stored in the $\mathrm{N}_{2} \mathrm{H}_{4}$ moiety can be recovered as $\mathrm{H}_{2}$. The real grand challenge is to dehydrogenate the $\mathrm{N}_{2} \mathrm{H}_{4}$ group in HB under mild conditions. The key point is to find a suitable reactive and selective catalyst, active in dehydrogenating both $\mathrm{BH}_{3}$ and $\mathrm{N}_{2} \mathrm{H}_{4}$ (6), while avoiding the occurrence of the side reaction producing $\mathrm{NH}_{3}$. Hence, $\mathrm{HB}$ could be ideally dehydrogenated into $5 \mathrm{~mol} \mathrm{H}_{2}$ per mol $\mathrm{HB}$. Great efforts were devoted to synthesize a highly selective catalyst that can achieve the completely dehydrogenated HB [5, 104-107]. Different catalysts for catalytic dehydrogenation from $\mathrm{HB}$ are summarized in Table 1:

$$
\begin{gathered}
\mathrm{N}_{2} \mathrm{H}_{4} \longrightarrow \mathrm{N}_{2}+2 \mathrm{H}_{2} \\
\mathrm{~N}_{2} \mathrm{H}_{4} \longrightarrow \frac{4}{3} \mathrm{NH}_{3}+\frac{1}{3} \mathrm{~N}_{2} \\
\mathrm{~N}_{2} \mathrm{H}_{4} \mathrm{BH}_{3}+3 \mathrm{H}_{2} \mathrm{O} \longrightarrow \mathrm{B}(\mathrm{OH})_{3}+\mathrm{N}_{2}+5 \mathrm{H}_{2}
\end{gathered}
$$

Singh and coworkers have studied the hydrogen evolution reaction from a mixture of $\mathrm{N}_{2} \mathrm{H}_{4}$ and $\mathrm{NH}_{3} \mathrm{BH}_{3}$ $\left(\mathrm{N}_{2} \mathrm{H}_{4} / \mathrm{NH}_{3} \mathrm{BH}_{3}=1: 1\right)$ in the presence of the $\mathrm{Ni}_{0.99} \mathrm{Pt}_{0.01}$ nanocatalysts at 25 and $50^{\circ} \mathrm{C}$ and proposed that the Ni-based bimetallic catalysts can be used to release five equivalents of $\mathrm{H}_{2}$ and one equivalent of $\mathrm{N}_{2}$ from an aqueous solution of $\mathrm{HB}$ [7]. Following researches confirmed this proposal $[5,104]$. Hannauer and coworkers have investigated various transition metal chlorides as precursors of in situ forming catalysts by reduction in the presence of $\mathrm{HB}$ at $50^{\circ} \mathrm{C}$ [105]. They concluded that the dehydrogenation of HB is a twostep metal-catalyzed process, where first the hydrolysis of the $\mathrm{BH}_{3}$ moiety occurs and second the decomposition of the $\mathrm{N}_{2} \mathrm{H}_{4}$ moiety takes place. The metals studied can be classified into 3 groups: (1) Fe- and Re-based catalysts, showing an incomplete conversion $\left(<3 \mathrm{~mol} \mathrm{H}_{2}\right)$ in the hydrolysis of the $\mathrm{BH}_{3}$ group; (2) Co-, Ni-, Cu-, $\mathrm{Pd}-$, $\mathrm{Pt}-$, and $\mathrm{Au}-$ based catalysts, only active in the hydrolysis of $\mathrm{BH}_{3}$ group $(3 \mathrm{~mol}$ $\mathrm{H}_{2}$ per $\mathrm{mol} \mathrm{BH}_{3}$ of $\mathrm{HB}$ ); (3) Ru-, Rh-, and Ir-based catalysts, being also active in the decomposition of $\mathrm{N}_{2} \mathrm{H}_{4}$ group. With the in situ formed $\mathrm{Rh}(0)$ nanorods $(10 \times 4 \mathrm{~nm}), 4.1 \mathrm{~mol}\left(\mathrm{H}_{2}+\right.$ $\mathrm{N}_{2}$ ) per mol HB can be produced at $50^{\circ} \mathrm{C}$ [105]. It was found that most of the Ni-based bimetallic systems, with $\mathrm{Pt}, \mathrm{Ru}, \mathrm{Rh}$, or Ir as the second metal, outperform the monometallic $\mathrm{Ni}$, $\mathrm{Pt}, \mathrm{Ru}, \mathrm{Rh}$, and $\mathrm{Ir}$ catalysts at $50^{\circ} \mathrm{C}$ [104]. The performance achieved is $5.1 \pm 0.05 \mathrm{~mol}\left(\mathrm{~N}_{2}+\mathrm{H}_{2}\right)$ per mol (HB) with $\mathrm{Ni}_{0.89} \mathrm{Rh}_{0.11}$ (reductant: $\mathrm{NaBH}_{4}$ ) and $\mathrm{Ni}_{0.89} \mathrm{Ir}_{0.11}$ (reductant: $\mathrm{NH}_{3} \mathrm{BH}_{3}$ ) nanocatalysts. Particularly, the hydrogen selectivity reaching $93 \pm 1 \%$ and $5.79 \pm 0.05$ equiv. $\left(\mathrm{H}_{2}+\mathrm{N}_{2}\right)$ per 
TABLE 1: Catalytic performance of metal nanocatalysts for hydrogen generation from hydrazine borane (HB).

\begin{tabular}{|c|c|c|c|}
\hline Catalysts & Temperature $\left({ }^{\circ} \mathrm{C}\right)$ & $n\left(\mathrm{H}_{2}+\mathrm{N}_{2}\right) / n \mathrm{HB}$ & Reference \\
\hline $\mathrm{RhCl}_{3}$ precatalyst & 25 & 2.93 & {$[4]$} \\
\hline $\mathrm{RuCl}_{3}$ precatalyst & 25 & $\sim 2.9$ & {$[4]$} \\
\hline $\mathrm{Rh} \mathrm{NPs} / \mathrm{Al}_{2} \mathrm{O}_{3}$ & 25 & $\sim 2.6$ & {$[4]$} \\
\hline $\mathrm{Ru} \mathrm{NPs} / \mathrm{Al}_{2} \mathrm{O}_{3}$ & 25 & $\sim 2.7$ & {$[4]$} \\
\hline Rh NPs/hydroxyapatite & 25 & 3 & {$[101]$} \\
\hline Ni NPs/PSSMA & 25 & $2.6 \sim 3$ & {$[102]$} \\
\hline $\mathrm{NiCl}_{2}$ precatalyst & 25 & 3 & {$[103]$} \\
\hline Ni NPs/CTAB & 50 & $\sim 3.1$ & {$[5]$} \\
\hline Pt NPs/CTAB & 50 & 3 & {$[5]$} \\
\hline Ru NPs/CTAB & 50 & $3.30 \pm 0.05$ & {$[104]$} \\
\hline Rh NPs/CTAB & 50 & $3.30 \pm 0.05$ & {$[104]$} \\
\hline Ir NPs/CTAB & 50 & $2.25 \pm 0.05$ & {$[104]$} \\
\hline $\mathrm{Ni}_{0.97} \mathrm{Pt}_{0.03} \mathrm{NPs} / \mathrm{CTAB}$ & 50 & $5.07 \pm 0.05$ & {$[5]$} \\
\hline $\mathrm{Ni}_{0.89} \mathrm{Pt}_{0.11} \mathrm{NPs} / \mathrm{CTAB}$ & 50 & $5.79 \pm 0.05$ & [5] \\
\hline $\mathrm{Ni}_{0.77} \mathrm{Pt}_{0.23} \mathrm{NPs} / \mathrm{CTAB}$ & 50 & $5.29 \pm 0.05$ & {$[5]$} \\
\hline $\mathrm{Ni}_{0.89} \mathrm{Rh}_{0.11} \mathrm{NPs} / \mathrm{CTAB}$ & \multirow[t]{2}{*}{50} & \multirow[t]{2}{*}{$5.1 \pm 0.05$} & \multirow[t]{2}{*}[104]{} \\
\hline $\mathrm{Ni}_{0.89} \mathrm{Ir}_{0.11} \mathrm{NPs} / \mathrm{CTAB}$ & & & \\
\hline $\mathrm{Ni}_{0.77} \mathrm{Ru}_{0.23} \mathrm{NPs} / \mathrm{CTAB}$ & 50 & $4 \pm 0.05$ & {$[104]$} \\
\hline $\mathrm{RhCl}_{3}$ precatalyst & 50 & 4.1 & {$[105]$} \\
\hline $\mathrm{RuCl}_{3}$ precatalyst & \multirow{2}{*}{50} & \multirow{2}{*}{3.3} & \multirow{2}{*}{ [105] } \\
\hline $\mathrm{IrCl}_{3}$ precatalyst & & & \\
\hline Rh NPs/CTAB & 50 & $4.4 \pm 0.2$ & {$[106]$} \\
\hline Ni NPs/CTAB & 50 & $3.5 \pm 0.1$ & {$[106]$} \\
\hline $\mathrm{Rh}_{4} \mathrm{Ni} \mathrm{NPs} / \mathrm{CTAB}$ & 50 & $5.8 \pm 0.2$ & {$[106]$} \\
\hline 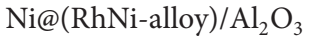 & 50 & $5.74 \pm 0.2$ & {$[107]$} \\
\hline $\mathrm{Ni}_{15}$ Rh-alloy/ $\mathrm{Al}_{2} \mathrm{O}_{3}$ & 50 & $\sim 4.15$ & {$[107]$} \\
\hline
\end{tabular}

$\mathrm{HB}$ could be released in the presence of $\mathrm{Ni}_{0.89} \mathrm{Pt}_{0.11} \mathrm{NPs}$ (reductant: $\mathrm{NaBH}_{4}$ ), suggesting that $9.7 \mathrm{wt} \%$ of $\mathrm{H}_{2}$ of the system $\mathrm{HB}-3 \mathrm{H}_{2} \mathrm{O}$ is recovered [5]. More recently, Zhang and coworkers reported that the $\mathrm{Rh}_{4} \mathrm{Ni}$ nanocatalyst exhibits high efficiency in dehydrogenation reaction of HB [106], as shown in Figure 4 . The hydrogen selectivity reaches almost $100 \%$ at $50^{\circ} \mathrm{C}$. Interestingly, the dehydrogenation of aqueous hydrazine borane catalyzed by the $\mathrm{Rh}_{4} \mathrm{Ni}$ alloy cannot be simply divided into two steps. Moreover, well-dispersed coreshell Ni@(RhNi-alloy) NPs supported on $\mathrm{Al}_{2} \mathrm{O}_{3}$ exhibited high hydrogen production rate with complete hydrogen generation of $\mathrm{HB}$, that is, $5.74 \pm 0.2$ equiv. $\left(\mathrm{H}_{2}+\mathrm{N}_{2}\right)$ per $\mathrm{HB}$ within $40 \mathrm{~min}$ at $50^{\circ} \mathrm{C}$ [107].

In addition, the hydrogen of $\mathrm{HB}$ can be released through the catalytic methanolysis at room temperature (7). Karahan and coworkers firstly reported the metal-catalyzed methanolysis of $\mathrm{HB}$ using a $\mathrm{NiCl}_{2}$ precatalyst at room temperature [103]. The methanolic solution of $\mathrm{HB}(\mathrm{HB} / \mathrm{Ni} \geq 200)$ can release 3 equiv. of $\mathrm{H}_{2}$ with a rate of $24 \mathrm{~mol} \mathrm{H}_{2}(\mathrm{~mol} \mathrm{Ni} \mathrm{min})^{-1}$ at room temperature. The catalytic methanolysis of $\mathrm{HB}$ can enable rapid and controllable hydrogen generation at ambient temperatures. The hydrogen capacity of this methanolysis reaction of $\mathrm{HB}$ is estimated to be only $3.5 \mathrm{wt} \%$, lower than that of the hydrolysis reaction of $\mathrm{HB}$ or $\mathrm{AB}$. This then makes this methanolysis reaction of $\mathrm{HB}$ less attractive than

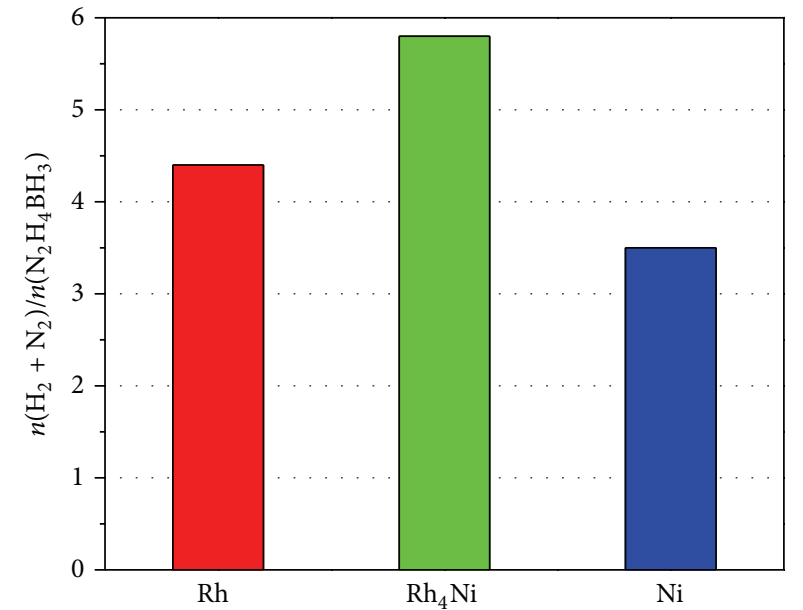

FIGURE 4: Evolution of the mol number of $\left(\mathrm{H}_{2}+\mathrm{N}_{2}\right)$ per mol of $\mathrm{N}_{2} \mathrm{H}_{4} \mathrm{BH}_{3}$ in the presence of $\mathrm{Rh}, \mathrm{Rh}_{4} \mathrm{Ni}$, and Ni nanocatalysts. The data are from [106].

the hydrolysis reaction. Very recently, Thoms and coworkers reported a study of the full dehydrogenation of $\mathrm{HB}$ to give $\mathrm{H}_{2}$ and $\mathrm{N}_{2}$ catalysed by a variety of group 4 metallocene alkyne complexes in THF at 25 and $50^{\circ} \mathrm{C}$ [108]. It was observed 
that the amount of hydrogen released is strongly dependent on both the metal and the cyclopentadienyl ligands. This work is the first example for a transition metal-catalysed homogenous process for the dehydrogenation of $\mathrm{HB}$ :

$$
\mathrm{N}_{2} \mathrm{H}_{4} \mathrm{BH}_{3}+4 \mathrm{CH}_{3} \mathrm{OH} \longrightarrow \mathrm{N}_{2} \mathrm{H}_{5} \mathrm{~B}\left(\mathrm{OCH}_{3}\right)_{4}+3 \mathrm{H}_{2}
$$

Hydrazine borane is a promising novel chemical hydrogen storage material because it stores $15.3 \mathrm{wt} \%(\mathrm{H})$ and can dehydrogenate in mild conditions. It can release $5 \mathrm{~mol} \mathrm{H}_{2}$ and $1 \mathrm{~mol} \mathrm{~N}_{2}$ per mol $\mathrm{HB}$ via the hydrolysis of $\mathrm{BH}_{3}$ moiety and the decomposition of $\mathrm{N}_{2} \mathrm{H}_{4}$ moiety in the presence of a suitable catalyst. The hydrolysis reaction system (HB$2 \mathrm{H}_{2} \mathrm{O}$ ) can ideally release $12.2 \mathrm{wt} \% \mathrm{H}$ (excess GHSC) and the byproduct gas $\mathrm{N}_{2}$ is inert towards fuel cells. Similar to $\mathrm{AB}$ hydrolysis, byproducts with strong $\mathrm{B}-\mathrm{O}$ bonds are produced during the hydrolysis reaction, which are difficult to regenerate the $\mathrm{B}-\mathrm{O}$ bonds to $\mathrm{B}-\mathrm{H}$ bonds due to the stability of $\mathrm{B}-\mathrm{O}$ bonds. Compared to $\mathrm{AB}$, it has a higher potential owing to a superior excess gravimetric hydrogen storage capacity and the possibility to decompose the $\mathrm{N}_{2} \mathrm{H}_{4}$ moiety without liberation of $\mathrm{NH}_{3}$. The current challenge is to find suitable reactive and selective catalysts to get a conversion of $100 \%$ while having selectivity in hydrogen of $100 \%$.

\section{Conclusion}

Ammonia borane and hydrazine borane store $19.6 \mathrm{wt} \%$ and $15.3 \mathrm{wt} \%$ hydrogen, respectively, whose dehydrogenation can be approached by either pyrolysis or solvolysis. They have the potential to be used as hydrogen sources suitable for portable fuel cells. This review has summarized some recent progresses on the nanocatalysts for hydrogen generation from catalytic solvolysis of ammonia borane and hydrazine borane. Significant progresses have been obtained in the development of nanocatalysts with high efficiency and low cost, which makes $\mathrm{AB}$ and $\mathrm{HB}$ promising candidates for some specialized applications of power generation (e.g., emergency or portable power). However, big challenges still remain for practical application of nanocatalysts, such as catalyst cost, deactivation, and control of the reaction kinetics. We are looking forward to the further progress of nanocatalysts for catalytic dehydrogenation of $\mathrm{AB}$ and $\mathrm{HB}$ in the future.

\section{Conflict of Interests}

The authors declare that there is no conflict of interests regarding the publication of this paper.

\section{Acknowledgments}

Our work in this area has been supported by the National Natural Science Foundation of China (no. 21103074), the Natural Science Foundation of Jiangxi Province of China (nos. 20114BAB203010 and 20132BAB203014), Jiangxi Provincial Department of Science and Technology (no. 20111BDH80023), and Scientific Research Foundation of Graduate School of Jiangxi Province (YC2013-S105). Zhang-Hui Lu was supported by the Sponsored Program for Cultivating Youths of Outstanding Ability in Jiangxi Normal University, Young Scientist Foundation of Jiangxi Province (20133BCB23011), and “Ganpo Talent 555” Project of Jiangxi Province.

\section{References}

[1] L. Schlapbach and A. Züttel, "Hydrogen-storage materials for mobile applications," Nature, vol. 414, no. 6861, pp. 353-358, 2001.

[2] P. Chen, Z. Xiong, J. Luo, J. Lin, and K. L. Tan, "Interaction of hydrogen with metal nitrides and imides," Nature, vol. 420, no. 6913, pp. 302-304, 2002.

[3] Z. Xiong, C. K. Yong, G. Wu et al., "High-capacity hydrogen storage in lithium and sodium amidoboranes," Nature Materials, vol. 7, no. 2, pp. 138-141, 2008.

[4] S. Karahan, M. Zahmakran, and S. Özkar, "Catalytic hydrolysis of hydrazine borane for chemical hydrogen storage: highly efficient and fast hydrogen generation system at room temperature," International Journal of Hydrogen Energy, vol. 36, no. 8, pp. 4958-4966, 2011.

[5] J. Hannauer, O. Akdim, U. B. Demirci et al., "High-extent dehydrogenation of hydrazine borane $\mathrm{N}_{2} \mathrm{H}_{4} \mathrm{BH}_{3}$ by hydrolysis of $\mathrm{BH}_{3}$ and decomposition of $\mathrm{N}_{2} \mathrm{H}_{4}$," Energy and Environmental Science, vol. 4, no. 9, pp. 3355-3358, 2011.

[6] K. S. Sanjay, X.-B. Zhang, and Q. Xu, "Room-temperature hydrogen generation from hydrous hydrazine for chemical hydrogen storage," Journal of the American Chemical Society, vol. 131, no. 29, pp. 9894-9895, 2009.

[7] S. K. Singh, Z.-H. Lu, and Q. Xu, “Temperature-induced enhancement of catalytic performance in selective hydrogen generation from hydrous hydrazine with Ni-based nanocatalysts for chemical hydrogen storage," European Journal of Inorganic Chemistry, no. 14, pp. 2232-2237, 2011.

[8] U. B. Demirci and P. Miele, "Cobalt in $\mathrm{NaBH}_{4}$ hydrolysis," Physical Chemistry Chemical Physics, vol. 12, no. 44, pp. 1465114665, 2010.

[9] Y. S. Chua, P. Chen, G. Wu, and Z. Xiong, "Development of amidoboranes for hydrogen storage," Chemical Communications, vol. 47, no. 18, pp. 5116-5129, 2011.

[10] X. Gu, Z.-H. Lu, H.-L. Jiang, T. Akita, and Q. Xu, "Synergistic catalysis of metal-organic framework-immobilized au-pd nanoparticles in dehydrogenation of formic acid for chemical hydrogen storage," Journal of the American Chemical Society, vol. 133, no. 31, pp. 11822-11825, 2011.

[11] X. Gu, Z.-H. Lu, and Q. Xu, "High-connected mesoporous metal-organic framework," Chemical Communications, vol. 46, no. 39, pp. 7400-7402, 2010.

[12] Z. H. Lu and Q. Xu, "Recent progress in boron- and nitrogenbased chemical hydrogen storage," Functional Materials Letters, vol. 5, Article ID 1230001, 2012.

[13] C. W. Hamilton, R. T. Baker, A. Staubitz, and I. Manners, "B-N compounds for chemical hydrogen storage," Chemical Society Reviews, vol. 38, no. 1, pp. 279-293, 2009.

[14] A. Staubitz, A. P. M. Robertson, and I. Manners, "Ammonia-Borane and related compounds as dihydrogen sources," Chemical Reviews, vol. 110, no. 7, pp. 4079-4124, 2010.

[15] T. Hugle, M. F. Kuhnel, and D. Lent, "Hydrazine borane: a promiding hydrogen storage material," Journal of the American Chemical Society, vol. 131, pp. 7444-7446, 2009.

[16] Z. Li, G. Zhu, G. Lu, S. Qiu, and X. Yao, "Ammonia borane confined by a metal-organic framework for chemical hydrogen 
storage: enhancing kinetics and eliminating ammonia," Journal of the American Chemical Society, vol. 132, no. 5, pp. 1490-1491, 2010.

[17] C. A. Jaska, K. Temple, A. J. Lough, and I. Manners, “Transition metal-catalyzed formation of boron-nitrogen bonds: catalytic dehydrocoupling of amine-borane adducts to form aminoboranes and borazines," Journal of the American Chemical Society, vol. 125, no. 31, pp. 9424-9434, 2003.

[18] M. E. Bluhm, M. G. Bradley, R. Butterick III, U. Kusari, and L. G. Sneddon, "Amineborane-based chemical hydrogen storage: enhanced ammonia borane dehydrogenation in ionic liquids," Journal of the American Chemical Society, vol. 128, no. 24, pp. 7748-7749, 2006.

[19] U. B. Demirci and P. Miele, "Sodium borohydride versus ammonia borane, in hydrogen storage and direct fuel cell applications," Energy and Environmental Science, vol. 2, no. 6, pp. 627637, 2009.

[20] U. Sanyal, U. B. Demirci, B. R. Jagirdar, and P. Miele, "Hydrolysis of ammonia borane as a hydrogen source: fundamental issues and potential solutions towards implementation," ChemSusChem, vol. 4, no. 12, pp. 1731-1739, 2011.

[21] B. Peng and J. Chen, "Ammonia borane as an efficient and lightweight hydrogen storage medium," Energy and Environmental Science, vol. 1, no. 4, pp. 479-483, 2008.

[22] M. Yadav and Q. Xu, "Liquid-phase chemical hydrogen storage materials," Energy \& Environmental Science, vol. 5, pp. 96989725, 2012.

[23] H.-L. Jiang, S. K. Singh, J.-M. Yan, X.-B. Zhang, and Q. Xu, "Liquid-Phase chemical hydrogen storage: catalytic hydrogen generation under ambient conditions," ChemSusChem, vol. 3, no. 5, pp. 541-549, 2010.

[24] H.-L. Jiang and Q. Xu, "Catalytic hydrolysis of ammonia borane for chemical hydrogen storage," Catalysis Today, vol. 170, no. 1, pp. 56-63, 2011.

[25] Q. Xu and M. Chandra, "A portable hydrogen generation system: catalytic hydrolysis of ammonia-borane," Journal of Alloys and Compounds, vol. 446-447, pp. 729-732, 2007.

[26] M. Chandra and Q. Xu, "A high-performance hydrogen generation system: transition metal-catalyzed dissociation and hydrolysis of ammonia-borane," Journal of Power Sources, vol. 156, no. 2, pp. 190-194, 2006.

[27] M. Chandra and Q. Xu, "Room temperature hydrogen generation from aqueous ammonia-borane using noble metal nanoclusters as highly active catalysts," Journal of Power Sources, vol. 168, no. 1, pp. 135-142, 2007.

[28] A. Aijaz, A. Karkamkar, Y. J. Choi et al., "Immobilizing highly catalytically active pt nanoparticles inside the pores of metal-organic framework: a double solvents approach," Journal of the American Chemical Society, vol. 134, pp. 13926-13929, 2012.

[29] Ö. Metin, Ş. Şahin, and S. Özkar, "Water-soluble poly(4styrenesulfonic acid-co-maleic acid) stabilized ruthenium(0) and palladium(0) nanoclusters as highly active catalysts in hydrogen generation from the hydrolysis of ammonia-borane," International Journal of Hydrogen Energy, vol. 34, no. 15, pp. 63046313, 2009.

[30] S. Akabyrak and S. Özkar, "Ruthenium(0) nanoparticles supported on xonotlite nanowire: a long-lived catalyst for hydrolytic dehydrogenation of ammonia-borane," Dalton Transactions, vol. 43, pp. 1797-1805, 2014.
[31] M. Rakap and S. Özkar, "Zeolite confined palladium(0) nanoclusters as effective and reusable catalyst for hydrogen generation from the hydrolysis of ammonia-borane," International Journal of Hydrogen Energy, vol. 35, no. 3, pp. 1305-1312, 2010.

[32] S. Akbayrak, P. Erdek, and S. Özkar, "Hydroxyapatite supported ruthenium(0) nanoparticles catalyst in hydrolytic dehydrogenation of ammonia borane: insight to the nanoparticles formation and hydrogen evolution kinetics," Applied Catalysis $B$, vol. 142, pp. 187-195, 2013.

[33] G. P. Rachiero, U. B. Demirci, and P. Miele, "Facile synthesis by polyol method of a ruthenium catalyst supported on $\gamma-\mathrm{Al}_{2} \mathrm{O}_{3}$ for hydrolytic dehydrogenation of ammonia borane," Catalysis Today, vol. 170, no. 1, pp. 85-92, 2011.

[34] H. Y. Liang, G. Z. Chen, S. Desinan, R. Rosei, F. Rosei, and D. L. Ma, "In situ facile synthesis of ruthenium nanocluster catalyst supported on carbon black for hydrogen generation from the hydrolysis of ammonia-borane," International Journal of Hydrogen Energy, vol. 37, pp. 17921-17927, 2012.

[35] S. Akbayrak and S. Özkar, "Ruthenium(0) nanoparticles supported on multiwalled carbon nanotube as highly active catalyst for hydrogen generation from ammonia-borane," ACS Applied Materials \& Interfaces, vol. 4, pp. 6302-6310, 2012.

[36] P. X. Xi, F. J. Chen, G. Q. Xie et al., "Surfactant free RGO/Pd nanocomposites as highly active heterogeneous catalysts for the hydrolytic dehydrogenation of ammonia borane for chemical hydrogen storage," Nanoscale, vol. 4, pp. 5597-5601, 2012.

[37] N. Cao, W. Luo, and G. Z. Cheng, "One-step synthesis of graphene supported $\mathrm{Ru}$ nanoparticles as efficient catalysts for hydrolytic dehydrogenation of ammonia borane," International Journal of Hydrogen Energy, vol. 38, pp. 11964-11972, 2013.

[38] Q. L. Yao, W. M. Shi, G. Feng et al., "Ultrafine Ru nanoparticles embedded in $\mathrm{SiO}_{2}$ nanospheres: highly efficient catalysts for hydrolytic dehydrogenation of ammonia borane," Journal of Power Sources, vol. 257, pp. 293-299, 2014.

[39] Q. Xu and M. Chandra, "Catalytic activities of non-noble metals for hydrogen generation from aqueous ammonia-borane at room temperature," Journal of Power Sources, vol. 163, no. 1, pp. 364-370, 2006.

[40] J.-M. Yan, X.-B. Zhang, S. Han, H. Shioyama, and Q. Xu, "Ironnanoparticle-catalyzed hydrolytic dehydrogenation of ammonia borane for chemical hydrogen storage," Angewandte Chemie-International Edition, vol. 47, no. 12, pp. 2287-2289, 2008.

[41] J.-M. Yan, X.-B. Zhang, H. Shioyama, and Q. Xu, "Room temperature hydrolytic dehydrogenation of ammonia borane catalyzed by Co nanoparticles," Journal of Power Sources, vol. 195, no. 4, pp. 1091-1094, 2010.

[42] T. Umegaki, J.-M. Yan, X.-B. Zhang, H. Shioyama, N. Kuriyama, and $\mathrm{Q}$. Xu, "Preparation and catalysis of poly(N-vinyl-2pyrrolidone) (PVP) stabilized nickel catalyst for hydrolytic dehydrogenation of ammonia borane," International Journal of Hydrogen Energy, vol. 34, no. 9, pp. 3816-3822, 2009.

[43] A. K. Figen, M. B. Piskin, B. Coskuner, and V. Imamoglu, "Synthesis, structural characterization, and hydrolysis of Ammonia Borane $\left(\mathrm{NH}_{3} \mathrm{BH}_{3}\right)$ as a hydrogen storage carrier," International Journal of Hydrogen Energy, vol. 38, pp. 16215-16228, 2013.

[44] Ö. Metin, V. Mazumder, S. Özkar, and S. Sun, "Monodisperse nickel nanoparticles and their catalysis in hydrolytic dehydrogenation of ammonia borane," Journal of the American Chemical Society, vol. 132, no. 5, pp. 1468-1469, 2010. 
[45] Ö. Metin, S. Özkar, and S. Sun, "Monodisperse nickel nanoparticles supported on $\mathrm{SiO}_{2}$ as an effective catalyst for the hydrolysis of ammonia-borane," Nano Research, vol. 3, no. 9, pp. 676684, 2010

[46] P. Z. Li, A. Aijaz, and Q. Xu, "Highly dispersed surfactant-free nickel nanoparticles and their remarkable catalytic activity in hydrolysis of ammonia borane for hydrogen generation," Angewandte Chemie International Edition, vol. 51, pp. 6753-6756, 2012.

[47] T. Umegaki, Q. Xu, and Y. Kojima, "Effect of L-arginine on the catalytic activity and stability of nickel nanoparticles for hydrolytic dehydrogenation of ammonia borane," Journal of Power Sources, vol. 216, pp. 363-367, 2012.

[48] M. Zahmkiran and S. Özkar, "Transition metal nanoparticles in catalysis for the hydrogen generation from the hydrolysis of ammonia-borane," Topics in Catalysis, vol. 56, pp. 1171-1183, 2013.

[49] J. Du, F. Y. Cheng, M. Si, J. Liang, Z. L. Tao, and J. Chen, "Nanoporous Ni-based catalysts for hydrogen generation from hydrolysis of ammonia borane," International Journal of Hydrogen Energy, vol. 38, pp. 5768-5774, 2013.

[50] N. Patel, R. Fernandes, S. Gupta, R. Edla, D. C. Kothari, and A. Mitoello, "Co-B catalyst supported over mesoporous silica for hydrogen production by catalytic hydrolysis of ammonia borane: a study on influence of pore structure," Applied Catalysis $B$, vol. 140, pp. 125-132, 2013.

[51] Y. C. Luo, Y. H. Liu, Y. Hung, X. Y. Liu, and C. Y. Mou, "Mesoporous silica supported cobalt catalysts for hydrogen generation in hydrolysis of ammonia borane," International Journal of Hydrogen Energy, vol. 38, pp. 7280-7290, 2013.

[52] S. B. Kalidindi, M. Indirani, and B. R. Jagirdar, "First row transition metal ion-assisted ammonia-borane hydrolysis for hydrogen generation," Inorganic Chemistry, vol. 47, no. 16, pp. 7424-7429, 2008.

[53] S. B. Kalidindi, U. Sanyal, and B. R. Jagirdar, "Nanostructured $\mathrm{Cu}$ and $\mathrm{Cu} @ \mathrm{Cu} 2 \mathrm{O}$ core shell catalysts for hydrogen generation from ammonia-borane," Physical Chemistry Chemical Physics, vol. 10, no. 38, pp. 5870-5874, 2008.

[54] Y. Yamada, K. Yano, Q. Xu, and S. Fukuzumi, " $\mathrm{Cu} / \mathrm{Co}_{3} \mathrm{O}_{4}$ nanoparticles as catalysts for hydrogen evolution from ammonia borane by hydrolysis," Journal of Physical Chemistry C, vol. 114, no. 39, pp. 16456-16462, 2010.

[55] Y. Yamada, K. Yano, and S. Fukuzumi, "Catalytic application of shape-controlled $\mathrm{Cu}_{2} \mathrm{O}$ particles protected by $\mathrm{Co}_{3} \mathrm{O}_{4}$ nanoparticles for hydrogen evolution from ammonia borane," Energy and Environmental Science, vol. 5, no. 1, pp. 5356-5363, 2012.

[56] M. Kaya, M. Zahmakiran, S. Özkar, and M. Volkan, “Copper(0) nanoparticles supported on silica-coated cobalt ferrite magnetic particles: cost effective catalyst in the hydrolysis of ammoniaborane with an exceptional reusability performance," ACS Applied Materials \& Interfaces, vol. 4, pp. 3866-3873, 2012.

[57] Y. W. Yang, Z. H. Lu, Y. J. Hu, Z. J. Zhang, W. M. Shi, and X. S. Chen, "Facile in situ synthesis of copper nanoparticles supported on graphene for hydrolytic dehydrogenation of ammonia borane," RSC Advances, vol. 4, pp. 13749-13752, 2014.

[58] Z.-H. Lu, H.-L. Jiang, M. Yadav, K. Aranishi, and Q. Xu, "Synergistic catalysis of Au-Co@SiO ${ }_{2}$ nanospheres in hydrolytic dehydrogenation of ammonia borane for chemical hydrogen storage," Journal of Materials Chemistry, vol. 22, no. 11, pp. 50655071, 2012.

[59] J.-M. Yan, X.-B. Zhang, T. Akita, M. Haruta, and Q. Xu, "One-step seeding growth of magnetically recyclable AU@Co core-shell nanoparticles: Highly efficient catalyst for hydrolytic dehydrogenation of ammonia borane," Journal of the American Chemical Society, vol. 132, no. 15, pp. 5326-5327, 2010.

[60] Q. L. Zhu, J. Li, and Q. Xu, "Immobilizing metal nanoparticles to metal-organic frameworks with size and location control for optimizing catalytic performance," Journal of the American Chemical Society, vol. 135, pp. 10210-10213, 2013.

[61] H.-L. Jiang, T. Umegaki, T. Akita, X.-B. Zhang, M. Haruta, and Q. Xu, "Bimetallic Au-Ni nanoparticles embedded in $\mathrm{SiO}_{2}$ nanospheres: synergetic catalysis in hydrolytic dehydrogenation of ammonia borane," Chemistry, vol. 16, no. 10, pp. 3132-3137, 2010.

[62] G. P. Rachiero, U. B. Demirci, and P. Miele, "Bimetallic RuCo and $\mathrm{RuCu}$ catalysts supported on $\gamma-\mathrm{Al}_{2} \mathrm{O}_{3}$. A comparative study of their activity in hydrolysis of ammonia-borane," International Journal of Hydrogen Energy, vol. 36, no. 12, pp. 7051-7065, 2011.

[63] G. Z. Chen, S. Desinan, R. Rosei, F. Rosei, and D. L. Ma, "Synthesis of Ni-Ru alloy nanoparticles and their high catalytic activity in dehydrogenation of ammonia borane," Chemistry, vol. 18, pp. 7925-7930, 2012.

[64] G. Chen, S. Desinan, R. Nechache, R. Rosei, F. Rosei, and D. Ma, "Bifunctional catalytic/magnetic Ni@Ru core-shell nanoparticles," Chemical Communications, vol. 47, no. 22, pp. 6308-6310, 2011.

[65] C. F. Yao, L. Zhuang, Y. L. Cao, X. P. Ai, and H. X. Yang, "Hydrogen release from hydrolysis of borazane on Pt- and Nibased alloy catalysts," International Journal of Hydrogen Energy, vol. 33, no. 10, pp. 2462-2467, 2008.

[66] F. Cheng, H. Ma, Y. Li, and J. Chen, "Nil-xPtx $(x=0-0.12)$ hollow spheres as catalysts for hydrogen generation from ammonia borane," Inorganic Chemistry, vol. 46, no. 3, pp. 788794, 2007.

[67] D. Sun, V. Mazumder, Ö. Metin, and S. Sun, "Catalytic hydrolysis of ammonia borane via cobalt palladium nanoparticles," ACS Nano, vol. 5, no. 8, pp. 6458-6464, 2011.

[68] C. M. Li, J. Y. Zhou, W. Gao et al., "Binary Cu-Co catalysts derived from hydrotalcites with excellent activity and recyclability towards $\mathrm{NH}_{3} \mathrm{BH}_{3}$ dehydrogenation," Journal of Materials Chemistry A, vol. 1, pp. 5370-5376, 2013.

[69] J. M. Yan, Z. L. Wang, H. L. Wang, and Q. Jiang, "Rapid and energy-efficient synthesis of a graphene-CuCo hybrid as a high performance catalyst," Journal of Materials Chemistry A, vol. 22, pp. 10990-10993, 2012.

[70] Z. H. Lu, J. P. Li, A. L. Zhu et al., "Catalytic hydrolysis of ammonia borane via magnetically recyclable copper iron nanoparticles for chemical hydrogen storage," International Journal of Hydrogen Energy, vol. 38, pp. 5330-5337, 2013.

[71] J.-M. Yan, X.-B. Zhang, S. Han, H. Shioyama, and Q. Xu, "Magnetically recyclable Fe-Ni alloy catalyzed dehydrogenation of ammonia borane in aqueous solution under ambient atmosphere," Journal of Power Sources, vol. 194, no. 1, pp. 478-481, 2009.

[72] F. Y. Qiu, Y. J. Wang, Y. P. Wang et al., "Dehydrogenation of ammonia borane catalyzed by in situ synthesized Fe-Co nanoalloy in aqueous solution," Catalysis Today, vol. 170, no. 1, pp. 64-68, 2011.

[73] W. Q. Feng, L. Yang, N. Cao et al., "In situ facile synthesis of bimetallic CoNi catalyst supported on graphene for hydrolytic dehydrogenation of amine borane," International Journal of Hydrogen Energy, vol. 39, pp. 3371-3380, 2014.

[74] H.-L. Jiang, T. Akita, and Q. Xu, "A one-pot protocol for synthesis of non-noble metal-based core-shell nanoparticles under 
ambient conditions: toward highly active and cost-effective catalysts for hydrolytic dehydrogenation of $\mathrm{NH}_{3} \mathrm{BH}_{3}$," Chemical Communications, vol. 47, no. 39, pp. 10999-11001, 2011.

[75] J. Wang, Y. L. Qin, X. Liu, and X. B. Zhang, "In situ synthesis of magnetically recyclable graphene-supported Pd@Co core-shell nanoparticles as efficient catalysts for hydrolytic dehydrogenation of ammonia borane," Journal of Materials Chemistry, vol. 22, pp. 12468-12470, 2012.

[76] L. Yang, W. Luo, and G. Z. Cheng, "Graphene-supported Agbased core-shell nanoparticles for hydrogen generation in hyrolysis of ammonia borane and methylamine borane," ACS Applied Materials \& Interfaces, vol. 5, pp. 8231-8240, 2013.

[77] N. Cao, J. Su, W. Luo, and G. Z. Cheng, "Hydrolytic dehydrogenation of ammonia borane and methylamine borane catalyzed by graphene supported Ru@Ni core-shell nanoparticles," International Journal of Hydrogen Energy, vol. 39, pp. 426-435, 2014.

[78] K. Aranishi, H.-L. Jiang, T. Akita, M. Haruta, and Q. Xu, "One-step synthesis of magnetically recyclable $\mathrm{Au} / \mathrm{Co} / \mathrm{Fe}$ triplelayered core-shell nanoparticles as highly efficient catalysts for the hydrolytic dehydrogenation of ammonia borane," Nano Research, vol. 4, no. 12, pp. 1233-1241, 2011.

[79] H.-L. Wang, J.-M. Yan, Z.-L. Wang, and Q. Jiang, “One-step synthesis of $\mathrm{Cu@FeNi} \mathrm{core-shell} \mathrm{nanoparticles:} \mathrm{highly} \mathrm{active}$ catalyst for hydrolytic dehydrogenation of ammonia borane," International Journal of Hydrogen Energy, vol. 37, pp. 102291035, 2012.

[80] X. Y. Meng, L. Yang, N. Cao et al., "Graphenesupported trimetalliccore-shell Cu@CoNi nanoparticles for catalytic hydrolysis ammine borane," ChemPlusChem, vol. 79, pp. 325-332, 2014.

[81] F. Y. Qiu, Y. L. Dai, L. Li et al., "Synthesis of Cu@FeCo core-shell nanoparticles for the catalytic hydrolysis of ammonia borane," International Journal of Hydrogen Energy, vol. 39, pp. 436-441, 2014.

[82] X. C. Shen, M. Dai, M. Gao, Z. B. Wang, B. Zhao, and W. P. Ding, "Core-shell structured Cu@CoCr catalyst: synthesis and catalytic performance for hydrolysis of ammonia borane aqueous solution," Chinese Journal of Inorganic Chemistry, vol. 29, pp. 999-1006, 2013.

[83] L. Yang, J. Su, W. Luo, and G. Z. Cheng, "Strategic synthesis of graphene supported trimetallic Ag-based core-shell nanoparticles toward hydrolytic dehydrogenation of amine boranes," International Journal of Hydrogen Energy, vol. 39, pp. 33603370, 2014.

[84] L. Yang, J. Su, X. Y. Meng, W. Luo, and G. Z. Cheng, "In situ synthesis of graphene supported Ag@CoNi core-shell nanoparticles as highly efficient catalysts for hydrogen generation from hydrolysis of ammonia borane and methylamine borane," Journal of Materials Chemistry A, vol. 1, pp. 10016-10023, 2013.

[85] F. Y. Qiu, G. Liu, L. Li et al., "Synthesis of triple-layered Ag@Co@Ni core-shell nanoparticles for the catalytic dehydrogenation of ammonia borane," Chemistry, vol. 20, pp. 505-509, 2014.

[86] P. V. Ramachandran and P. D. Gagare, "Preparation of ammonia borane in high yield and purity, methanolysis, and regeneration," Inorganic Chemistry, vol. 46, no. 19, pp. 7810-7817, 2007.

[87] H. Erdoǧan, Ö. Metin, and S. Özkar, "In situ-generated PVPstabilized palladium $(0)$ nanocluster catalyst in hydrogen generation from the methanolysis of ammonia-borane," Physical Chemistry Chemical Physics, vol. 11, no. 44, pp. 10519-10525, 2009.
[88] H. Erdoan, Ö. Metin, and S. Özkar, "Hydrogen generation from the methanolysis of ammonia borane catalyzed by in situ generated, polymer stabilized ruthenium(0) nanoclusters," Catalysis Today, vol. 170, no. 1, pp. 93-98, 2011.

[89] H.-B. Dai, X.-D. Kang, and P. Wang, "Ruthenium nanoparticles immobilized in montmorillonite used as catalyst for methanolysis of ammonia borane," International Journal of Hydrogen Energy, vol. 35, no. 19, pp. 10317-10323, 2010.

[90] S. B. Kalidindi, A. A. Vernekar, and B. R. Jagirdar, "Co- $\mathrm{Co}_{2}$ B, Ni$\mathrm{Ni}_{3} \mathrm{~B}$ and $\mathrm{Co}-\mathrm{Ni}-\mathrm{B}$ nanocomposites catalyzed ammonia-borane methanolysis for hydrogen generation," Physical Chemistry Chemical Physics, vol. 11, no. 5, pp. 770-775, 2009.

[91] S. Çalişkan, M. Zahmakiran, and S. Özkar, "Zeolite confined rhodium(0) nanoclusters as highly active, reusable, and longlived catalyst in the methanolysis of ammonia-borane," Applied Catalysis B: Environmental, vol. 93, no. 3-4, pp. 387-394, 2010.

[92] D. H. Sun, V. Mazumder, O. Metin, and S. H. Sun, "Methanolysis of ammonia borane by CoPd nanoparticles," ACS Catalysis, vol. 2, pp. 1290-1295, 2012.

[93] Q. L. Yao, M. Huang, Z. H. Lu et al., "Menthanolysis of ammonia borane by shape-controlled mesoporous copper nanostructures for hydrogen generation," submitted to Nano Energy.

[94] V. J. Goubeau and E. Ricker, "Borinhydrazine und seine pyrolyseprodukte," Zeitschrift für Anorganische und Allgemeine Chemie, vol. 310, pp. 123-142, 1961.

[95] C. Cakanyildirim, E. Petit, U. B. Demirci et al., "Gaining insight into the catalytic dehydrogenation of hydrazine borane in water," International Journal of Hydrogen Energy, vol. 37, pp. 15983-15991, 2012.

[96] V. S. Nguyen, S. Swinnen, J. Leszczynski, and M. T. Nguyen, "Formation and hydrogen release of hydrazine bisborane: transfer vs. attachment of a borane," Physical Chemistry Chemical Physics, vol. 13, no. 14, pp. 6649-6656, 2011.

[97] R. Moury, G. Moussa, U. B. Demirci et al., "Hydrazine borane: synthesis, characterization, and application prospects in chemical hydrogen storage," Physical Chemistry Chemical Physics, vol. 14, no. 5, pp. 1768-1777, 2012.

[98] Z. Qian, B. Pathak, and R. Ahuja, "Energetic and structural analysis of $\mathrm{N}_{2} \mathrm{H}_{4} \mathrm{BH}_{3}$ inorganic solid and its modified material for hydrogen storage," International Journal of Hydrogen Energy, vol. 38, pp. 6718-6725, 2013.

[99] N. Vinh-Son, S. Swinnen, M. H. Matus, M. T. Nguyen, and D. A. Dixon, "The effect of the $\mathrm{NH}_{2}$ substituent on $\mathrm{NH}_{3}$ : hydrazine as an alternative for ammonia in hydrogen release in the presence of boranes and alanes," Physical Chemistry Chemical Physics, vol. 11, no. 30, pp. 6339-6344, 2009.

[100] G. Rasul, G. K. S. Prakash, and G. A. Olah, "B-H bond protonation in mono- and diprotonated borane complexes $\mathrm{H}_{3} \mathrm{BX}(\mathrm{X}=$ $\mathrm{N}_{2} \mathrm{H}_{4}, \mathrm{NH}_{2} \mathrm{OH}$, and $\mathrm{H}_{2} \mathrm{O}_{2}$ ) involving hypercoordinate boron," Inorganic Chemistry, vol. 38, pp. 5876-5878, 1999.

[101] D. Elik, S. Karahan, M. Zahmakran, and S. Özkar, "Hydrogen generation from the hydrolysis of hydrazine-borane catalyzed by rhodium( 0 ) nanoparticles supported on hydroxyapatite," International Journal of Hydrogen Energy, vol. 37, no. 6, pp. 51435151, 2012.

[102] S. Sencanli, S. Karahan, and S. Ozkar, "Poly(4-styrenesulfonic acid-co-maleic acid) stabilized nickel(0) nanoparticles: highly active and cost effective catalyst in hydrogen generation from the hydrolysis of hydrazine borane," International Journal of Hydrogen Energy, vol. 38, pp. 14693-14703, 2013. 
[103] S. Karahan, M. Zahmakiran, and S. Özkar, "Catalytic methanolysis of hydrazine borane: a new and efficient hydrogen generation system under mild conditions," Dalton Transactions, vol. 41, no. 16, pp. 4912-4918, 2012.

[104] Ç. Çakanyildirim, U. B. Demirci, T. Şener, Q. Xu, and P. Miele, "Nickel-based bimetallic nanocatalysts in high-extent dehydrogenation of hydrazine borane," International Journal of Hydrogen Energy, vol. 37, pp. 9722-9729, 2012.

[105] J. Hannauer, O. Akdim, U. B. Demirci et al., "High-extent dehydrogenation of hydrazine borane $\mathrm{N}_{2} \mathrm{H}_{4} \mathrm{BH}_{3}$ by hydrolysis of $\mathrm{BH}_{3}$ and decomposition of $\mathrm{N}_{2} \mathrm{H}_{4}$," Energy and Environmental Science, vol. 4, no. 9, pp. 3355-3358, 2011.

[106] D. C. Zhang, K. Aranishi, A. K. Singh, U. B. Demirci, and Q. $\mathrm{Xu}$, "The synergistic effect of Rh-Ni catalysts on the highlyefficient dehydrogenation of aqueous hydrazine borane for chemical hydrogen storage," Chemical Communications, vol. 48, pp. 11945-11947, 2012.

[107] C. M. Li, Y. B. Dou, J. Liu et al., "Synthesis of supported Ni@ (RhNi-alloy) nanocomposites as an efficient catalyst to-wards hydrogen generation from $\mathrm{N}_{2} \mathrm{H}_{4} \mathrm{BH}_{3}$," Chemical Communications, vol. 49, pp. 9992-9994, 2013.

[108] J. Thoms, M. Klahn, A. Spannenberg, and T. Beweries, "Group 4 metallocene catalysed full dehydrogenation of hydrazine borane," Dalton Transactions, vol. 42, pp. 14668-14672, 2013. 

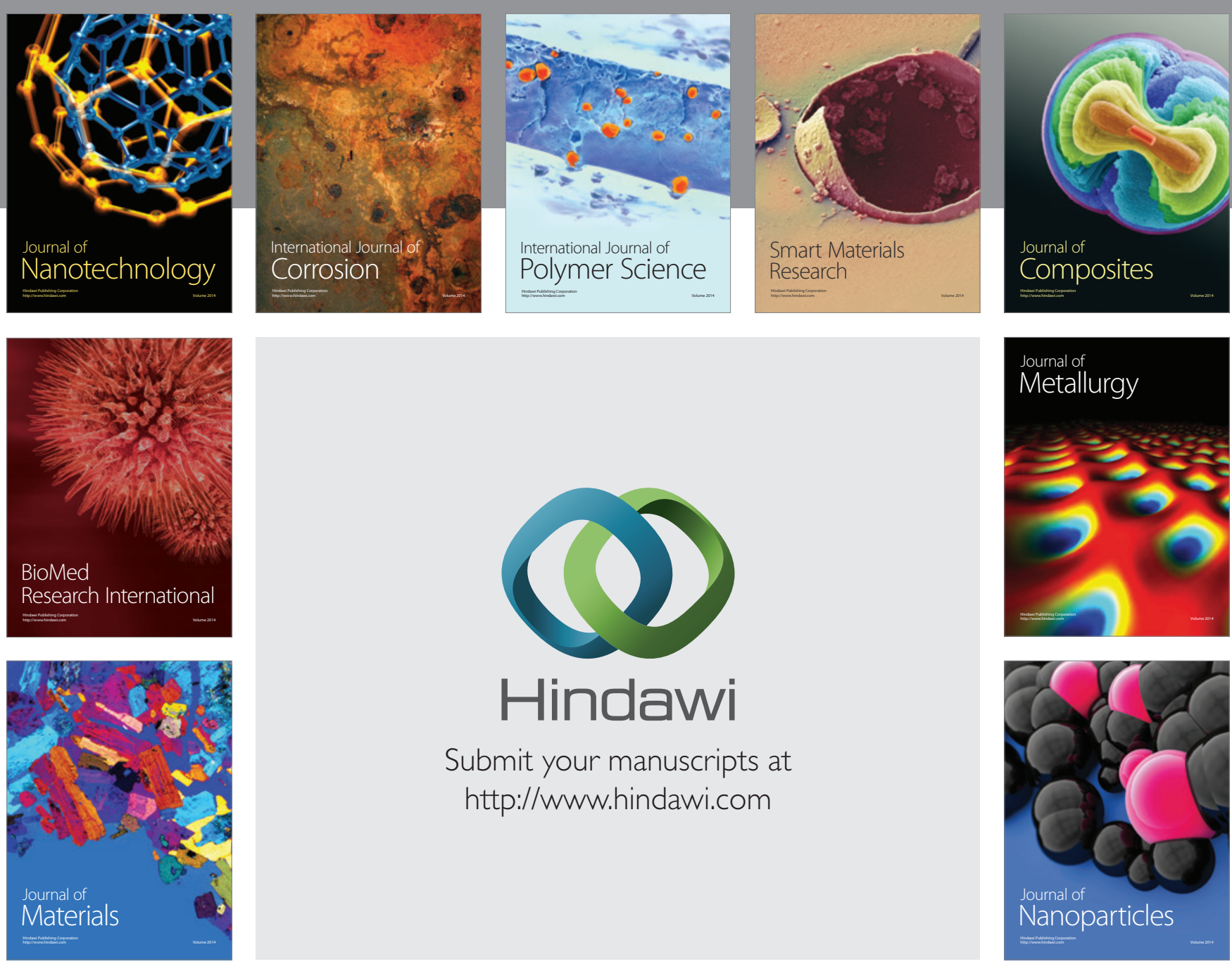

Submit your manuscripts at http://www.hindawi.com
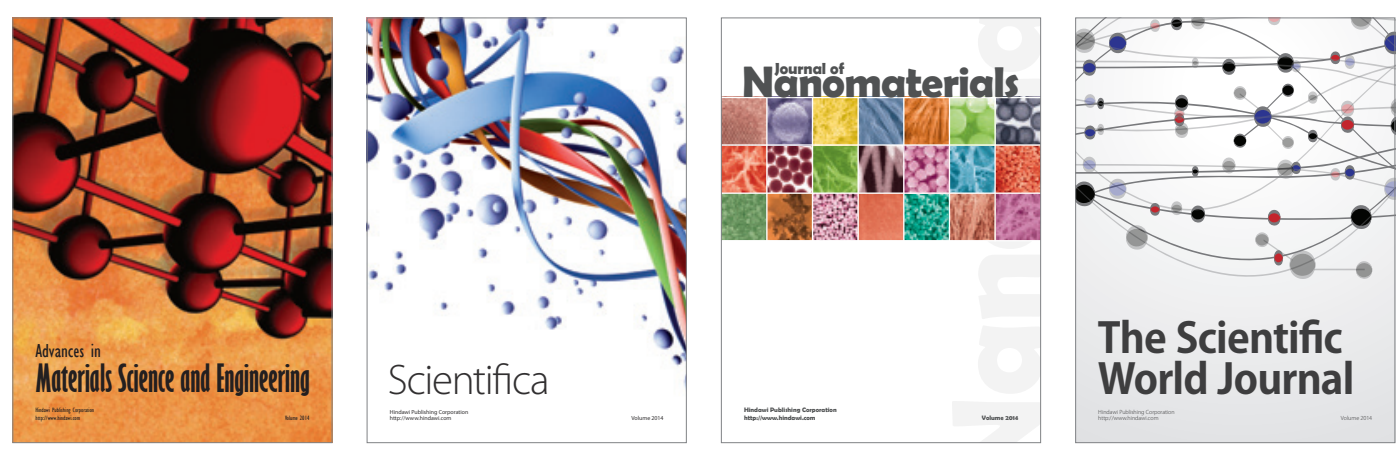

\section{The Scientific World Journal}
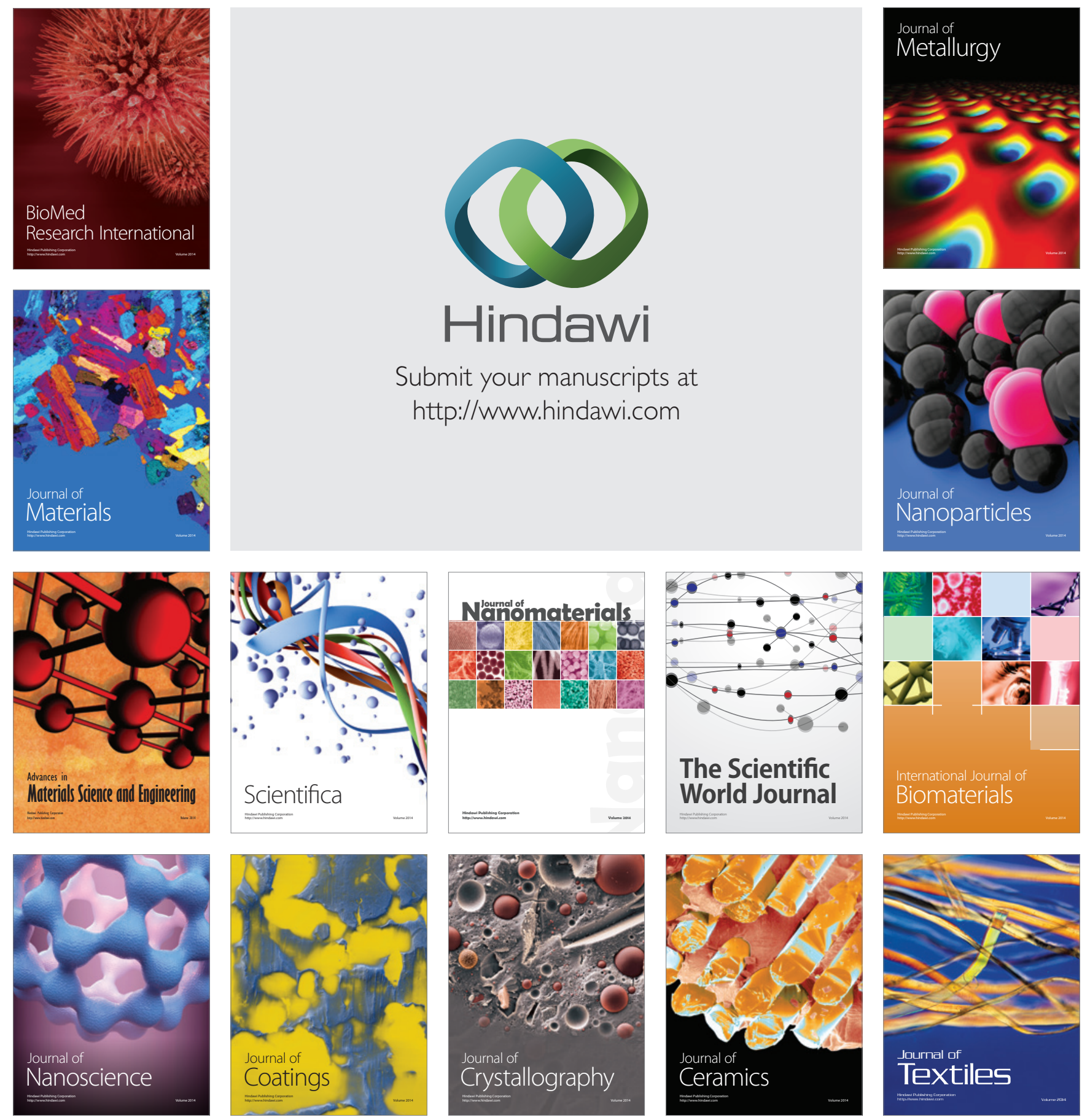